\title{
Retention period after treatment of posterior crossbite with maxillary expansion: a systematic review
}

\author{
Julia Garcia Costa¹, Thaís Magalhães Galindoํ․, Claudia Trindade Mattos², Adriana de Alcantara Cury-Saramago²
}

DOI: http://dx.doi.org/10.1590/2177-6709.22.2.035-044.oar

Objective: The aim of this systematic review was to evaluate the duration of the retention period in growing patients undergoing maxillary expansion and its relation with posterior crossbite stability. Methods: Search strategies were executed for electronic databases Cochrane Library, Web of Science, PubMed and Scopus, which were completed on January 15, 2016. The inclusion criteria included randomized, prospective or retrospective controlled trials in growing subjects with posterior crossbite; treated with maxillary expanders; retention phase after expansion; post-retention phase of at least 6 months. The exclusion criteria were anterior crossbite, craniofacial anomalies, surgery or another orthodontic intervention; case reports; author's opinions articles, thesis, literature reviews and systematic reviews. The risk of bias of selected articles was assessed with Cochrane risk of bias tool for RCTs and Downs and Black checklist for non-RCTs. Results: A total of 156 titles/abstracts was retrieved, 44 full-texts were examined, and 6 articles were selected and assessed for their methodological quality. The retention period after maxillary expansion ranged between 4 weeks and 16 months. Fixed (acrylic plate, Haas, Hyrax and quad-helix) or removable (Hawley and Hawley expander) appliances were used for retention. Conclusions: Six months of retention with either fixed or removable appliances seem to be enough to avoid relapse or to guarantee minimal changes in a short-term follow-up.

Keywords: Crossbite. Maxillary expansion. Retainer.

Objetivo: o objetivo da presente revisão sistemática foi avaliar a duração do período de contenção e a estabilidade do tratamento ortodôntico com expansão maxilar em pacientes em crescimento com mordida cruzada posterior. Métodos: foram realizadas buscas estratégicas nas bases eletrônicas: Cochrane Library, Web of Science, PubMed e Scopus, até 15 de janeiro de 2016. Os critérios de inclusão foram: estudos clínicos controlados e randomizados, prospectivos ou retrospectivos, de pacientes em crescimento com mordida cruzada; tratados com aparelhos expansores maxilares, com fase de contenção pós-expansão e no mínimo seis meses de fase de pós-contenção. Os critérios de exclusão foram: mordida cruzada anterior, anomalias craniofaciais, cirurgia ou outro tratamento ortodôntico; relato de casos; artigos de opinião; teses; revisões de literatura e revisões sistemáticas. O risco de viés dos artigos selecionados foi avaliado a partir do Cochrane risk of bias tool para ensaios clínicos randomizados e Downs and Black checklist para ensaios clínicos não randomizados. Resultados: a busca resultou em 156 títulos/resumos, sendo 44 textos examinados na íntegra. Foram selecionados 6 artigos para o acesso à qualidade metodológica. A duração do período de contenção ocorreu entre 4 semanas e 6 meses. Aparelhos fixos (aparelho em acrilico, Haas, Hyrax e quad-helix) ou removíveis (Hawley e Hawley com expansor) foram utilizados na fase de contenção. Conclusão: parece que seis meses de contenção com aparelhos fixos ou removíveis são suficientes para evitar a recidiva ou garantir mudanças mínimas em um curto período de acompanhamento pós-contenção.

Palavras-chave: Mordida cruzada. Expansão Maxilar. Contenção.

${ }^{1}$ Orthodontics department, Universidade Federal Fluminense, Niterói, Brazil. ${ }^{2}$ Professor of Orthodontics, Dental Clinic department, Universidade Federal Fluminense, Niterói, Brazil.

» The authors report no commercial, proprietary or financial interest in the products or companies described in this article.

Submitted: January 29, 2016 - Revised and accepted: September 12, 2016
How to cite this article: Costa JG, Galindo TM, Mattos CT, Cury-Saramago AA. Retention period after treatment of posterior crossbite with maxillary expansion: a systematic review. Dental Press J Orthod. 2017 Mar-Apr;22(2):35-44. DOI: http://dx.doi.org/10.1590/2177-6709.22.2.035-044.oar

Contact address: Adriana de Alcantara Cury-Saramago

Rua Mário Santos Braga, 30, 2º andar, sl. 214 - Campus do Valonguinho

Centro - Niterói/RJ - Brazil - CEP: 24.020-140

E-mail: adrianacury@id.uff.br 


\section{INTRODUCTION}

Posterior crossbite is a common malocclusion in the deciduous and mixed dentitions, with prevalence rates of $7.5 \%{ }^{1}$ to $22 \%,{ }^{2}$ and in the permanent dentition with rates of $10.2 \%$ to $14.4 \% .^{3}$

The etiology of this malocclusion may be dental, skeletal and/or functional. ${ }^{4}$ Few studies have reported the self-correction of posterior crossbite in the deciduous dentition, related to the discontinuation of sucking habits and chronic respiratory childhood diseases. ${ }^{5,6}$ However, this condition is usually not self-corrected. .,7,8 $^{4}$

Studies with adolescents and adults have revealed that patients presenting posterior crossbite have an increased risk to develop craniomandibular disorders, showing more signs and symptoms of these conditions. ${ }^{2,5}$ Several authors suggest the early treatment of crossbites to prevent mandibular dysfunction as well as craniofacial asymmetry. ${ }^{7-10}$

Adults can be submitted to maxillary expansion, although there are controversies regarding the nonsurgical treatment. ${ }^{11,12}$

Various methods have been suggested for correction and retention after treatment of posterior crossbite in growing patients: Haas, ${ }^{8,13-16}$ Hyrax, ${ }^{14,15,17,18}$ quad-helix appliance (QDH), ${ }^{4,714,15,19-21}$ removable plates, ${ }^{4,7,9,20-22}$ grinding ${ }^{7,10}$ and edgewise fixed appliances. ${ }^{23}$

The successful treatment of a posterior crossbite is frequently reached not only by the expansion of the maxilla. In growing subjects, the treatment must also achieve the reestablishment of the normal growth rate on a longitudinal basis, ${ }^{24}$ as well as improve the oral and general health. ${ }^{25}$

No consensus among authors exists regarding the optimal retention period after maxillary expansion. Some authors recommend that the retention phase should last for 6 weeks, ${ }^{19}$ while others advocate $6^{4,21}$ or 8 months. ${ }^{8}$ Thus, a systematic review of the literature was deemed appropriate.

The aim of this systematic review was to evaluate the duration of the retention period in growing patients undergoing maxillary expansion and its relation with posterior crossbite stability. The PICOS is shown in Table 1.

\section{MATERIAL AND METHODS}

This systematic review was registered on the $\mathrm{Na}-$ tional Institute of Health Research Database:

www.crd.york.ac.uk/prospero.
The inclusion criteria were randomized controlled trials (RTCs) and controlled trials in human growing subjects; experimental group presenting posterior crossbite; treatment with maxillary expanders; retention phase after expansion; and a minimum 6-month postretention phase.

The exclusion criteria were subjects presenting anterior crossbite, craniofacial anomalies, previous surgery or another orthodontic intervention; case reports; author's opinions articles, thesis, literature reviews and systematic reviews.

To identify the studies, detailed search strategies were developed and executed in the following electronic databases: Cochrane Library, Web of Science, PubMed and Scopus (Table 2). All electronic searches were conducted between May 28, 2015 and January 15, 2016. No restrictions for language or publication date were used.

The results were compiled into a reference manager (EndNote X5, Thomson Reuters), and duplicate records were excluded.

Two authors independently reviewed titles and abstracts according to the inclusion and exclusion criteria. Any disagreement was solved by consultation with two others authors until mutual agreement was reached and initial selection was completed.

Full texts of articles where it was not possible to decide for inclusion or exclusion only by reading the title and abstract were also screened to confirm their eligibility. Two authors independently read the full texts of the articles previously selected.

After electronic searches and the initial selection process, a supplementary hand search was implemented by checking the references of each selected study. Afterwards, two authors independently performed a structured quality assessment of the selected articles based on risk of bias. The Cochrane risk of bias tools ${ }^{26}$ was used for randomized studies, and the Downs and Black checklist $^{27}$ for non-randomized studies. Any disagreement on the risk of bias assessment was resolved after consulting other two authors.

The following data from the included articles were extracted and independently compiled by two researchers: author/year; sample description; crossbite type; expander/ activation time; activation rate; retainer appliance and retention time; measurements; follow-up time; overcorrection; experimental group versus control group ( $p$ value); 
Table 1 - PICOS.

\begin{tabular}{ll}
\hline PICOS & Description \\
\hline Population & Growing subjects presenting posterior crossbite \\
\hline Intervention & Treated with maxillary expansion \\
\hline Comparison & Another maxillary expansion procedure, untreated crossbite subjects or untreated subjects without posterior crossbite \\
\hline Outcomes & Duration of the retention period after maxillary expansion and its relation with posterior crossbite stability \\
\hline Study design & Randomized controlled trials (RTCS) and controlled trials in human growing subjects \\
\hline
\end{tabular}

Table 2 - Search strategy in databases.

\begin{tabular}{|c|c|}
\hline Database & Search strategy \\
\hline Cochrane Library & $\begin{array}{l}\text { "palatal expansion technic" or "maxillary expansion" in Title, Abstract, Keywords and "retention" or "retainer" or "stability" or } \\
\text { "relapse" in Title, Abstract, Keywords and "crossbite" in Title, Abstract, Keywords not "case report" in Title, Abstract, Keywords } \\
\text { (Word variations have been searched) }\end{array}$ \\
\hline $\begin{array}{l}\text { Web of Science } \\
\text { (Database=SCI-EXPANDED, } \\
\text { SSCl, A\&HCl, CPCl-S, CPCl- } \\
\text { SSH, BKCl-S, BKCI-SSH) }\end{array}$ & $\begin{array}{l}\text { 1) TS=(palatal expansion technic OR maxillary expansion OR maxillary disjunction OR palatal disjunction OR expansion appliance } \\
\text { OR maxillary expander OR palatal expander OR maxillary expander) } \\
\text { 2) } T S=(\text { retention* OR retainer* OR relapse* OR stability*) } \\
\text { 3) } T S=\left(\text { crossbite*) }^{*} \text { 4) \#1 AND \#2 AND \#3 }\right. \\
\text { 5) } \mathrm{TI}=\text { (case report OR case series OR adult*) } \\
\text { 6) \#4 AND NOT \#5 }\end{array}$ \\
\hline PubMed & $\begin{array}{l}\text { (palatal expansion technique[MeSH Terms]) OR "maxillary expansion"[Title/Abstract]) OR "maxillary disjunction"[Title/Abstract]) } \\
\text { OR "palatal disjunction"[Title/Abstract]) AND "retention"[Title/Abstract]) OR orthodontic retainer[MeSH Terms]) OR "stability" [Title/ } \\
\text { Abstract]) OR "relapse"[Title/Abstract]) AND "crossbite"[Title/Abstract]) NOT "case report"[Title]) NOT "case series"[Title]) NOT } \\
\text { adult(Title] }\end{array}$ \\
\hline Scopus & $\begin{array}{l}\text { TITLE-ABS-KEY(palatal expansion technique) OR TITLE-ABS-KEY("maxillary expansion") OR TITLE-ABS-KEY("maxillary } \\
\text { disjunction") OR TITLE-ABS-KEY("palatal disjunction") AND TITLE-ABS-KEY("retention") OR TITLE-ABS-KEY("retainers") OR TITLE- } \\
\text { ABS-KEY("relapse") OR TITLE-ABS-KEY("post retention") OR TITLE-ABS-KEY("stability") OR TITLE-ABS-KEY("changes") AND TITLE- } \\
\text { ABS-KEY(crossbite) AND NOT TITLE-ABS-KEY("case report") AND NOT TITLE-ABS-KEY("case series") AND NOT TITLE-ABS- } \\
\text { KEY(adult) }\end{array}$ \\
\hline
\end{tabular}

relapse after follow-up time; crossbite correction stability after follow-up; conclusion.

In order to verify the percentage of relapse for each transversal measure given by the authors, the difference between the measure immediately after expansion (AE) and the measure after 6-month follow-up (FU) was calculated following the equation: [(AE-FU)x100/AE].

\section{RESULTS}

In the databases search, 281 articles were found. After duplicates were excluded, we screened 156 titles and abstracts; and 112 studies were excluded from this review; 44 full texts were screened, and 6 articles were selected according to the eligibility criteria. The search process is shown in the Prisma flow diagram (Fig 1).
Two articles included, which are randomized controlled trials, were assessed with the Cochrane tool and the corresponding graphs are shown in Figures 2 and 3. The non-randomized studies were classified according to their risk of bias, using the Downs and Black checklist, as: low risk, ${ }^{4}$ medium ${ }^{16}$ and high risk $^{8,22}$ (Table 3).

Data extracted from the included articles are displayed in Tables 4A and 4B. The retention period after maxillary expansion ranged from five $\mathrm{e}^{22}$ to sixteen months, ${ }^{16}$ and the appliances used were: fixed (acrylic plate expander, ${ }^{22}$ Haas, ${ }^{8,16}$ Hyrax $^{17}$ and quad-helix ${ }^{4,21}$ ) or removable (hawley ${ }^{4,22}$ and Hawley expander ${ }^{4,21,22}$ ).

The follow-up of these patients ranged from 6 months ${ }^{4}$ to $60^{16}$ months, and the relapses of the measurements described reached $0 \%{ }^{4}$ to $27 \% 0^{17}$. 

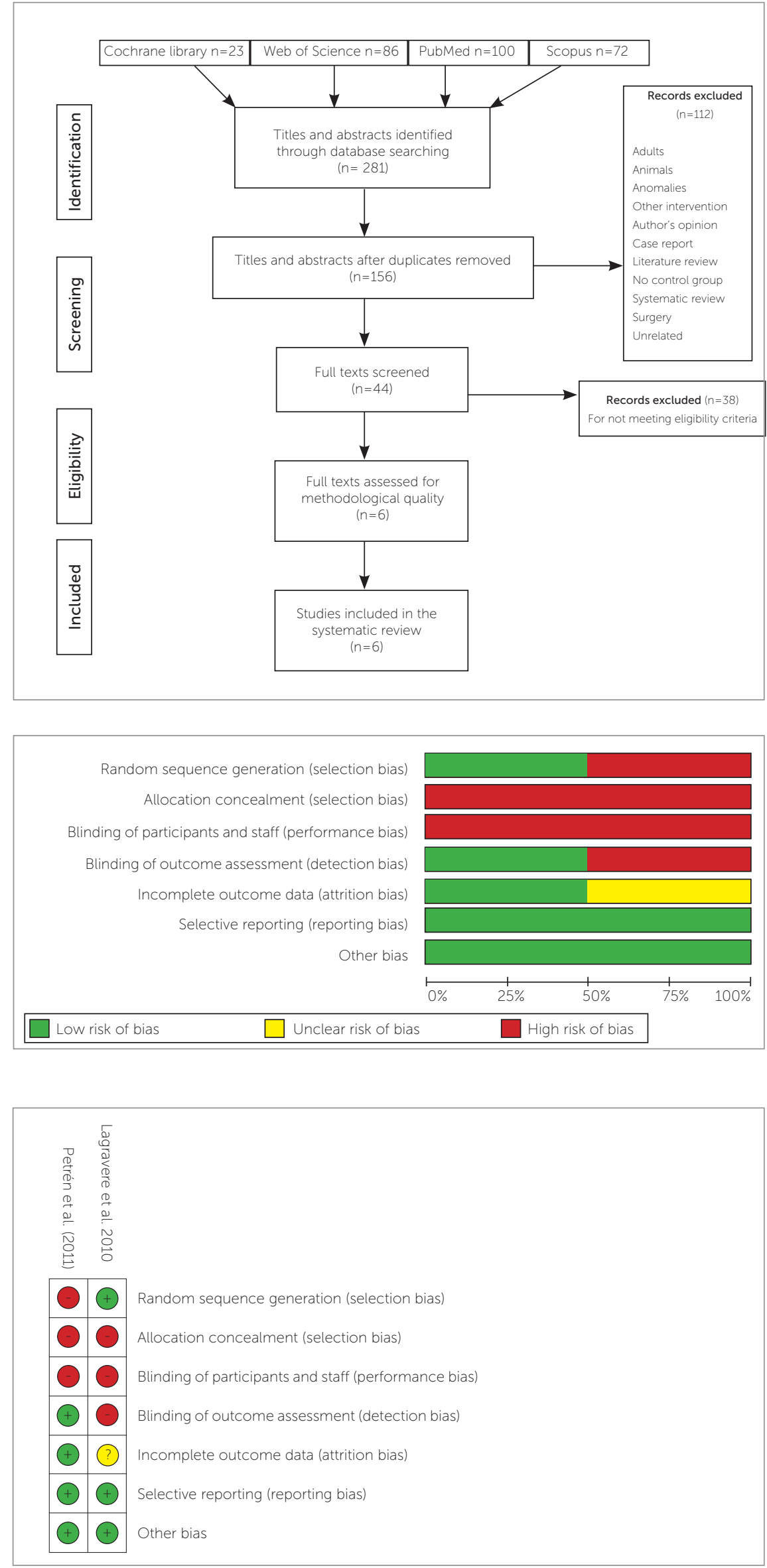

Figure 1 - Prisma flow diagram.

Figure 2 - Risk of bias graph for RCTs studies.

Figure 3 - Risk of bias summary for RCTs studies 
Table 3 - Downs and Black checklist for non-randomized studies.

\begin{tabular}{|c|c|c|c|c|c|c|}
\hline $\begin{array}{l}\text { ALL } \\
\text { CRITERIA }\end{array}$ & $\begin{array}{l}\text { DESCRIPTION OF CRITERIA } \\
\text { (with additional explanation as required, determined by consensus of raters) }\end{array}$ & $\begin{array}{l}\text { POSSIBLE } \\
\text { ANSWERS }\end{array}$ & $\begin{array}{c}\text { Cozzani } \\
\text { et } \mathrm{al}^{8}\end{array}$ & $\begin{array}{l}\text { Godoy } \\
\text { et } \mathrm{al}^{4}\end{array}$ & $\begin{array}{l}\text { Mutinelli } \\
\text { et al }{ }^{16}\end{array}$ & $\begin{array}{l}\text { Primožič } \\
\text { et } \mathrm{al}^{22}\end{array}$ \\
\hline 1 & Is the hypothesis/aim/objective of the study clearly described? Must be explicit & $0 / 1$ & 1 & 1 & 1 & 1 \\
\hline 2 & $\begin{array}{l}\text { Are the main outcomes to be measured clearly described in the Introduction or } \\
\text { Methods sections? }\end{array}$ & $0 / 1$ & 1 & 1 & 1 & 1 \\
\hline 3 & Are the characteristics of the patients included in the study clearly described? & $0 / 1$ & 1 & 1 & 1 & 1 \\
\hline 4 & Are the interventions of interest clearly described? & $0 / 1$ & 1 & 1 & 1 & 1 \\
\hline 5 & $\begin{array}{l}\text { Are the distributions of principal confounders in each group of subjects to be } \\
\text { compared clearly described? }\end{array}$ & $0 / 1 / 2$ & 0 & 2 & 2 & 0 \\
\hline 6 & Are the main findings of the study clearly described? & $0 / 1$ & 1 & 1 & 1 & 1 \\
\hline 7 & $\begin{array}{l}\text { Does the study provide estimates of the random variability in the data for the main } \\
\text { outcomes? }\end{array}$ & $0 / 1$ & 1 & 1 & 1 & 1 \\
\hline 8 & $\begin{array}{l}\text { Have all important adverse events that may be a consequence of the intervention } \\
\text { been reported? }\end{array}$ & $0 / 1$ & 1 & 1 & 0 & 1 \\
\hline 9 & Have the characteristics of patients lost to follow-up been described? & $0 / 1$ & 0 & 0 & 0 & 0 \\
\hline 10 & $\begin{array}{l}\text { Have actual probability values been reported (e.g. } 0.035 \text { rather than }<0.05) \text { for the } \\
\text { main outcomes except where the probability value is less than } 0.001 \text { ? }\end{array}$ & $0 / 1$ & 0 & 1 & 1 & 0 \\
\hline 11 & $\begin{array}{l}\text { Were the subjects asked to participate in the study representative of the entire } \\
\text { population from which they were recruited? }\end{array}$ & $0 / 0 / 1$ & 0 & 1 & 0 & 0 \\
\hline 12 & $\begin{array}{l}\text { Were those subjects who were prepared to participate representative of the entire } \\
\text { population from which they were recruited? }\end{array}$ & $0 / 0 / 1$ & 0 & 1 & 0 & 0 \\
\hline 13 & $\begin{array}{l}\text { Were the staff, places, and facilities where the patients were treated, representative of } \\
\text { the treatment the majority of patients receive? }\end{array}$ & $0 / 0 / 1$ & 0 & 1 & 0 & 0 \\
\hline 14 & Was an attempt made to blind study subjects to the intervention they have received? & $0 / 0 / 1$ & 0 & 0 & 0 & 0 \\
\hline 15 & $\begin{array}{l}\text { Was an attempt made to blind those measuring the main outcomes of the } \\
\text { intervention? }\end{array}$ & $0 / 0 / 1$ & 0 & 1 & 0 & 0 \\
\hline 16 & If any of the results of the study were based on "data dredging", was this made clear? & $0 / 0 / 1$ & 1 & 1 & 1 & 1 \\
\hline 17 & $\begin{array}{l}\text { In trials and cohort studies, do the analyses adjust for different lengths of follow-up of } \\
\text { patients, or in case control studies, is the time period between the intervention and } \\
\text { outcome the same for cases and controls? }\end{array}$ & $0 / 0 / 1$ & 1 & 0 & 0 & 1 \\
\hline 18 & Were the statistical tests used to assess the main outcomes appropriate? & $0 / 0 / 1$ & 1 & 1 & 1 & 1 \\
\hline 19 & Was compliance with the intervention/s reliable? & $0 / 0 / 1$ & 1 & 0 & 1 & 1 \\
\hline 20 & Were the main outcome measures used accurate (valid and reliable)? & $0 / 0 / 1$ & 1 & 1 & 1 & 1 \\
\hline 21 & $\begin{array}{l}\text { Were the patients in different intervention groups (trials and cohort studies) or were } \\
\text { the cases and controls (case-control studies) recruited from the same population? }\end{array}$ & $0 / 0 / 1$ & 0 & 1 & 0 & 0 \\
\hline 22 & $\begin{array}{l}\text { Were study subjects in different intervention groups (trials and cohort studies) or were } \\
\text { the cases and controls (case-control studies) recruited over the same time? }\end{array}$ & $0 / 0 / 1$ & 1 & 1 & 0 & 0 \\
\hline 23 & Were study subjects randomized to intervention groups? & $0 / 0 / 1$ & 0 & 1 & 0 & 0 \\
\hline 24 & $\begin{array}{l}\text { Was the randomized intervention assignment concealed from both patients and } \\
\text { health care staff until recruitment was complete and irrevocable? }\end{array}$ & $0 / 0 / 1$ & 0 & 0 & 0 & 0 \\
\hline 25 & $\begin{array}{l}\text { Was there adequate adjustment for confounding in the analyses from which the } \\
\text { main findings were drawn? }\end{array}$ & $0 / 0 / 1$ & 0 & 0 & 1 & 1 \\
\hline 26 & Were losses of patients to follow-up taken into account? & $0 / 0 / 1$ & 0 & 1 & 0 & 1 \\
\hline 27 & $\begin{array}{l}\text { Did the study have sufficient power to detect a clinically important effect where the } \\
\text { probability value for a difference being due to chance }<5 \%\end{array}$ & $1-5$ & 0 & 4 & 4 & 0 \\
\hline TOTAL & & Max. 32 & 13 & 25 & 18 & 14 \\
\hline
\end{tabular}

$0 / 1=\mathrm{No} /$ Yes; $0 / 1 / 2=\mathrm{No} / \mathrm{Partially} / \mathrm{Yes} ; 0 / 0 / 1=$ Unable to determine/No/Yes . 
Table 4A - Characteristics and data of included studies.

\begin{tabular}{|c|c|c|c|c|c|}
\hline Author/ Year & Sample description & Type of crossbite & $\begin{array}{l}\text { Expander/ Activation } \\
\text { time }\end{array}$ & Activation rate & $\begin{array}{l}\text { Retainer appliance/ } \\
\text { Retention time }\end{array}$ \\
\hline $\begin{array}{c}\text { Cozzani et } a l^{8} \\
\qquad(2007)\end{array}$ & $\begin{array}{l}\text { » Group A (TG) = } 31 \text { (20 F/11M) } \\
\text { CB experimental 7.3 } \pm 1 y \\
\text { » Group B (CG) = } 30(13 \mathrm{~F} / 17 \mathrm{M}) \\
\text { CB untreated } 8.4 \mathrm{y} \\
\text { » Group C }(\mathrm{CG})=30(13 \mathrm{~F} / 17 \mathrm{M}) \\
\text { CB untreated } 10.8 \mathrm{y}\end{array}$ & $\begin{array}{l}\text { unilateral or bilateral } \\
\text { posterior crossbite }\end{array}$ & $\begin{array}{l}\text { Haas Group A (primary } \\
\text { second molars and } \\
\text { canines) } \\
\text { mean } 20 \text { days (until } \\
\text { permanent first molars } \\
\text { correction) }\end{array}$ & $\begin{array}{l}\text { RME } \\
\text { once or twice/day } \\
0.25 \mathrm{~mm}-0.5 \mathrm{~mm} / \text { day }\end{array}$ & $\begin{array}{l}\text { Haas } \\
\text { at least } 8 \mathrm{~m} \\
\text { mean } 1.1 \mathrm{y}\end{array}$ \\
\hline $\begin{array}{l}\text { Lagravère } \\
\qquad{\text { et }{ }^{1{ }^{17}}}^{(2010)}\end{array}$ & $\begin{array}{l}\text { » Group TG }=20(15 \mathrm{~F} / 5 \mathrm{M}) \\
\text { CB experimental } 14.05 \pm 1.35 \mathrm{y} \\
\text { » Group } \mathrm{CG}=21(15 \mathrm{~F} / 6 \mathrm{M}) \\
\text { CB untreated } 12.86 \pm 1.19 \mathrm{y}\end{array}$ & $\begin{array}{l}\text { posterior } \\
\text { crossbite }\end{array}$ & $\begin{array}{l}\text { Hyrax } \\
\text { (until posterior } \\
\text { CB overcorrection) }\end{array}$ & $\begin{array}{l}\text { RME } \\
\text { twice/day } \\
0.5 \mathrm{~mm}\end{array}$ & $\begin{array}{l}\text { Hyrax/ } \\
6 \text { months }\end{array}$ \\
\hline $\begin{array}{c}\text { Godoy et al }{ }^{4} \\
\text { (2011) }\end{array}$ & $\begin{aligned} & \text { Group QDH= } 33(26 \mathrm{~F} / 7 \mathrm{M}) \\
& \text { CB-experimental } 8.00 \pm 0.79 y \\
& \text { Group EP }=33(18 \mathrm{~F} / 15 \mathrm{M}) \\
& \text { CB-experimental } 7.82 \pm 0.85 \mathrm{y} \\
& \text { Group CG }=33(14 \mathrm{~F} / 19 \mathrm{M}) \\
& \text { CB-untreated } 8.09 \pm 0.81 \mathrm{y}\end{aligned}$ & $\begin{array}{l}\text { unilateral posterior } \\
\text { crossbite }\end{array}$ & $\begin{array}{l}\text { QDH adjusted for buccal } \\
\text { root torque mean } \\
4.24 \pm 2.05 \mathrm{~m} \\
\text { EP acrylic covering } \\
\text { mean } 6.12 \pm 3.25 \mathrm{~m} \\
\text { (until CB correction) } \\
\text { evaluated every } \\
4 \text { weeks }\end{array}$ & $\begin{array}{l}\text { SME } \\
\text { once a month } \\
\text { QDH expanded } 1 \text { side to } \\
\text { pass central fossa; and the } \\
\text { other to the molar- } \\
\text { band } \\
\text { EP- } 0.25 \mathrm{~mm} / \text { week }\end{array}$ & $\begin{array}{l}\text { Plate placed/ } \\
\text { To be used } 24 \text { hours/ } \\
\text { day } \\
\text { for } 3 \text { months and for } \\
3 \text { more months just } \\
\text { at night }\end{array}$ \\
\hline $\begin{array}{l}\text { Petrén et } \mathrm{al}^{21} \\
\text { (2011) }\end{array}$ & $\begin{array}{l}\text { » Group QDH= } 20(11 \mathrm{~F} / 9 \mathrm{M}) \\
\text { CB-experimental } 9.00 \pm 1.19 \mathrm{y} \\
\text { » Group EP=15 (10F/5M) } \\
\text { 5M noncompliance excluded } \\
\text { CB-experimental } 8.5 \pm 1.02 \mathrm{y} \\
\text { » Group CG= } 20 \text { (9F/11M) } \\
\text { NCB- } 8.8 \pm 0.5 y\end{array}$ & $\begin{array}{l}\text { unilateral posterior } \\
\text { crossbite }\end{array}$ & $\begin{array}{l}\text { QDH adjusted for buccal } \\
\text { root torque QDH and EP } \\
\text { (until CB correction) } \\
\text { CG untreated }\end{array}$ & $\begin{array}{l}\text { SME } \\
\text { QDH } \\
\text { activated } 10 \mathrm{~mm} \text {, } \\
\text { reactivated every } 6 \text { weeks/ } \\
\text { recemented } \\
\text { EP } \\
0.2 \mathrm{~mm} / \text { week }\end{array}$ & $\begin{array}{l}\text { QDH } \\
6 \text { months } \\
\text { EP / } 6 \text { months } 24 \\
\text { hours/day }\end{array}$ \\
\hline $\begin{array}{c}\text { Primožič et al }{ }^{22} \\
\text { (2013) }\end{array}$ & $\begin{array}{l}\text { » Group TG= } 30(17 \mathrm{~F} / 13 \mathrm{M}) \\
\text { CB experimental }-5.3 \pm 0.7 \mathrm{y} \\
\text { » Group CG= } 30(17 \mathrm{~F} / 13) \mathrm{M} \\
\text { NCB- } 5.3 \pm 0.7 \mathrm{y}\end{array}$ & $\begin{array}{l}\text { unilateral posterior } \\
\text { crossbite, } \\
\text { mandibular } \\
\text { lateral shift }\end{array}$ & $\begin{array}{l}\text { Acrylic plate expander } \\
\text { cemented/ } \\
4 \text { weeks }\end{array}$ & $\begin{array}{l}\text { SSME } \\
0.25 \mathrm{~mm} / \\
\text { every } 2 \text { days }\end{array}$ & $\begin{array}{l}\text { Acrylic plate expander } \\
\text { inactive/ } \\
4 \text { weeks } \\
\text { Acrylic removable } \\
\text { plate/ } \\
4 \text { months }\end{array}$ \\
\hline $\begin{array}{l}\text { Mutinelli et al }{ }^{16} \\
\qquad \text { (2015) }\end{array}$ & 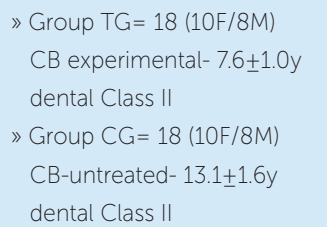 & $\begin{array}{l}\text { unilateral or bilateral } \\
\text { posterior crossbite }\end{array}$ & $\begin{array}{l}\text { Haas/(primary second } \\
\text { molars and canines) } \\
\text { mean } 28 \text { days (until } \\
\text { permanent first molars } \\
\text { correction) }\end{array}$ & $\begin{array}{l}\text { RME } \\
\text { once or twice/ day } \\
0.2 \mathrm{~mm}-0.4 \mathrm{~mm} / \text { day }\end{array}$ & $\begin{array}{l}\text { Haas/ } \\
7 \text { months } \\
1.4 \mathrm{y}\end{array}$ \\
\hline
\end{tabular}

$T G=$ Treatment group; $C G=$ Control group; $F=$ female; $M=$ male; $P F M=$ Permanent first molar; $P S M=$ Primary second $m o l a r ; I C=I n t e r c u s p i d$ canines; $y=$ years; $m=$ months; RME = Rapid maxillary expansion; $Q D H=$ Quad-Helix appliance;

$\mathrm{EP}=$ Expansion plate; $\mathrm{NCB}=$ Non crossbite group; $\mathrm{CB}=$ Crossbite; UPC = Unilateral posterior crossbite 
Table 4B - Characteristics and data of included studies.

\begin{tabular}{|c|c|c|c|c|c|c|c|}
\hline Author/ Year & Measurements & $\begin{array}{l}\text { Follow-up } \\
\text { time }\end{array}$ & $\begin{array}{l}\text { Overcorrec- } \\
\text { tion }\end{array}$ & $\begin{array}{l}\text { Experimental } \\
\text { group x Control } \\
\text { group (P value) }\end{array}$ & $\begin{array}{l}\text { Relapse measure- } \\
\text { ments after follow- } \\
\text { up }\end{array}$ & $\begin{array}{l}\text { Crossbite } \\
\text { corrected after } \\
\text { follow-up }\end{array}$ & Conclusion \\
\hline $\begin{array}{c}\text { Cozzaniet } a l^{8} \\
\text { (2007) }\end{array}$ & $\begin{array}{l}\text { » Maxillary arch width: } \\
\text { » PFM- center of the fossa } \\
\text { » PSM-center of the fossa } \\
\text { » IC-cusp tip } \\
\text { »DC }\end{array}$ & $\begin{array}{l}\text { minimum 1y } \\
\text { after appliance } \\
\text { removal } \\
2.4 \pm 1.7 y\end{array}$ & $\begin{array}{l}\text { yes - } \\
\text { primary teeth } \\
\text { no- } \\
\text { permanent first } \\
\text { molar }\end{array}$ & $\begin{array}{l}\text { PFM: } \leq 0.01 \\
\text { PSM: } \leq 0.01 \\
I C: \leq 0.05\end{array}$ & $\begin{array}{l}\text { PFM }=0.9 \% \\
P S M=6.0 \% \\
I C=5.5 \%\end{array}$ & yes & $\begin{array}{l}\text { Relapse: PFM < PSM } \\
\text { Overexpand PSM } \\
\text { PFM was stable for } 2 \text { y } 4 \mathrm{~m} \text { after } \\
\text { treatment }\end{array}$ \\
\hline $\begin{array}{l}\text { Lagravere } \\
\qquad{\text { et } a 1^{17}}^{(2010)}\end{array}$ & $\begin{array}{l}\text { »PC- center of pulp } \\
\text { chamber in molars } \\
\text { and tip of premolars } \\
\text { buccal pulp horn } \\
\text { » MBA-mesiobuccal root } \\
\text { apex of molars } \\
\text { »BA-buccal root apex } \\
\text { of premolars } \\
\text { »AlB-outer cortex of } \\
\text { alveolar bone at the } \\
\text { vertical level of the } \\
\text { root apex } \\
\text { »mm } \\
\text { »CBCT }\end{array}$ & $\begin{array}{l}\text { Before fixed } \\
\text { bonding }(12 \mathrm{~m}) \\
\text { long-term post- } \\
\text { relapse }\end{array}$ & yes & $\begin{array}{l}\text { all groups } \\
\mathrm{P}<.001\end{array}$ & $\begin{array}{l}\text { PC16-PC26 }=27 \% \\
\text { PC14-PC24 }=39 \% \\
\text { MBA16-MBA26=28\% } \\
\text { BA14-BA24 = 18 } \% \\
\text { AIB16-AIB26 }=51 \% \\
\text { AIB14-AIB24 }=20 \%\end{array}$ & yes & $\begin{array}{l}\text { aprox } 4 \mathrm{~mm} \text { (70\%) } \\
\text { expansion - at T4 } \\
\text { at molars } \\
\text { Dental expansion> } \\
\text { skeletal expansion } \\
\text { Midpalatal suture } \\
\text { separation on TG. } \\
\text { No significant changes } \\
\text { at the level of the } \\
\text { pterigoid plates } \mathrm{TG}=\mathrm{CG}\end{array}$ \\
\hline $\begin{array}{c}\text { Godoy et } \mathrm{al}^{4} \\
\text { (2011) }\end{array}$ & $\begin{array}{l}\text { Maxillary arch width: } \\
\text { PSM-center of the fossa } \\
\text { IC-cusp tip } \\
\text { DC }\end{array}$ & $\begin{array}{l}6 \mathrm{~m} \text { after } \\
\text { appliance } \\
\text { removal }\end{array}$ & no & $\begin{array}{l}\text { IMD: } \\
P<0.001 \\
\text { (QDH=EP; QDH } \neq \\
C G ; E P \neq C G) \\
\text { ICD: } \\
P=0.354\end{array}$ & $\begin{array}{l}\mathrm{PSF} \\
\mathrm{QDH}=2.2 \% \\
\mathrm{EP}=1.7 \% \\
\mathrm{IC} \\
\mathrm{QDH}=0.3 \% \mathrm{EP}=0 \%\end{array}$ & $\begin{array}{l}\text { yes } \\
9.1 \% \text { of the each } \\
\text { sample showed } \\
\text { relapse }\end{array}$ & $\begin{array}{l}\text { QDH }=E P \text { for correct posterior } \\
\text { crossbite } \\
\text { QDH> breakage } \\
E P>\text { lost appliances } \\
\text { QDH }<\text { treatment time } \\
\text { Treatment may be performed in } \\
\text { 1y for posterior CB correction } \\
\text { and } 6 \mathrm{~m} \text { for retention }\end{array}$ \\
\hline $\begin{array}{c}\text { Petrén et } \mathrm{al}^{21} \\
\text { (2011) }\end{array}$ & $\begin{array}{l}\text { Maxillary arch width: } \\
\text { PSM-gingival margin } \\
\text { (GM) } \\
\text { PSM-mesiobuccal cusp } \\
\text { tip (MCT) } \\
\text { IC-gingival margin } \\
\text { (GM) } \\
\text { IC-buccal cusp tip (BCT) } \\
\text { DC }\end{array}$ & $\begin{array}{l}\text { QDH and EP } \\
\text { group } \\
4 y \text { after } \\
\text { correction }\end{array}$ & no & $\begin{array}{l}\text { IMD (MCT): } \\
P=N R \\
(C G>Q D H, E P) \\
I C D(B C T): P=N R \\
(C G>Q D H)\end{array}$ & $\begin{array}{l}\text { PSM } \\
\text { QDH }=1.6 \% \\
E P=5.6 \% \\
I C(G M) \\
Q D H=4.9 \% \\
E P=5.6 \% \\
I C(B C T) \\
Q D H=1.2 \% \\
E P=0.6 \%\end{array}$ & yes & $\begin{array}{l}\text { The long-term stability of } \\
\text { crossbite correction in the } \\
\text { mixed dentition is favorable. } \\
\text { Results: QDH=EP }\end{array}$ \\
\hline $\begin{array}{c}\text { Primozic et al22 } \\
\text { (2013) }\end{array}$ & $\begin{array}{l}\text { Palatal surface area }\left(\mathrm{mm}^{2}\right) \\
\text { 3D digital } \\
\text { DC }\end{array}$ & $\begin{array}{l}12 \text { months later } \\
18 \text { months later } \\
30 \text { months later }\end{array}$ & yes & $\begin{array}{l}\text { Surface }\left(\mathrm{mm}^{2}\right) \text { : } \\
P=N R \\
N S(T G=C G)\end{array}$ & $\begin{array}{l}\text { Palatal surface area } \\
(\mathrm{TG})=-0.5 \%\end{array}$ & $\begin{array}{l}26.7 \% \text { of the TG } \\
\text { showed relapse }\end{array}$ & $\begin{array}{l}\text { Treatment of unilateral } \\
\text { CB in the deciduous dentition } \\
\text { also create conditions for } \\
\text { normal occlusal and craniofacial } \\
\text { development. } \\
\text { Improves facial symmetry } \\
\text { and increase palatal area and } \\
\text { volume }\end{array}$ \\
\hline $\begin{array}{l}\text { Mutinelli et al }{ }^{16} \\
\text { (2015) }\end{array}$ & $\begin{array}{l}\text { Maxillary arch width: } \\
\text { PSM and IC (mm); } \\
\text { 3D digital } \\
\text { DC }\end{array}$ & $\begin{array}{l}\text { In the } \\
\text { permanent } \\
\text { dentition } \\
5.3 \pm 0.8 y\end{array}$ & $\begin{array}{l}\text { yes - primary } \\
\text { teeth } \\
\text { no- } \\
\text { permanent } \\
\text { first molar }\end{array}$ & $\begin{array}{l}\text { IC } \\
P=0.02 \\
P S M \\
P=0.001\end{array}$ & $\begin{array}{l}\text { PSM }=1 \% \\
I C=5.1 \%\end{array}$ & yes & $\begin{array}{l}\text { In patients in canine } \\
\text { Class II, early treatment } \\
\text { of lateral CB with a } \\
\text { modified Haas expander } \\
\text { anchored to deciduous } \\
\text { teeth is effective and } \\
\text { presented stable results } \\
\text { until the stage of } \\
\text { permanent dentition }\end{array}$ \\
\hline
\end{tabular}

$T G=$ Treatment group; $C G=$ Control group; PFM= Permanent first molar; PSM= Primary second molar; $I C=I n t e r c u s p i d$ canines; $D C=$ Dental cast; $y=$ years; $\mathrm{m}=$ months; $\mathrm{RME}=$ Rapid maxillary expansion; $\mathrm{QDH}=$ Quad-Helix appliance; $\mathrm{EP}=$ Expansion plate; $\mathrm{IMD}=\mathbf{I n t e r m o l a r}$ distance; $\mathrm{ICD}=$ intercanine distance: $\mathrm{GM}=$ Gingival margin; $\mathrm{MCT}=$ Mesiobuccal cusp tips; $\mathrm{BCT}=$ Gingival margin and buccal cusp tips; NCB= Non crossbite group; CB= Crossbite; NS= Not significant; $\mathrm{NR}=$ Not reported. 


\section{DISCUSSION}

The duration of the steady retention after maxillary expansion that guarantees the correction of posterior crossbite is not well established in the literature and this was the main reason that led to this systematic review.

The evidence collected in this systematic review combined low, medium and high risk of bias studies. The main drawback in RCTs and non-RCTs was blinding, which is unfeasible in the assessed type of intervention. In non-RCTs, another main problem was the description of the characteristics of subjects lost to follow-up.

However, the heterogeneity among the studies made the comparison difficult. Dental and skeletal measures varied widely, as follows: intermolar distance measured between the center of the fossae of maxillary permanent first molars, ${ }^{4,8,16}$ measured between the mesiobuccal cusp tips and gingival margin, ${ }^{21}$ distance between the center of the fossae of maxillary primary second molars, ${ }^{8}$ intercanine distance measured between cusp tips, ${ }^{4,8,21}$ gingival margin, ${ }^{21}$ palatal surface area,${ }^{22}$ and distance of center of pulp chamber in molars and tip of premolar buccal pulp horn, mesial buccal root apex of molars, buccal root apex of premolars, outer cortex of alveolar bone at the vertical level of the root apex. ${ }^{17}$

The appliances used for maxillary expansion in the studies included were Haas, ${ }^{8,16}$ Hyrax, ${ }^{17}$ QDH, ${ }^{4,21}$ removable acrylic expansion plate, ${ }^{4,21}$ and cemented acrylic plate. ${ }^{22}$ All authors used the same expander appliance for retention of the maxillary expansion, $4,8,16,17,21,22$ except the quad-helix group in the study from Godoy et $\mathrm{al},{ }^{4}$ who used a removable Hawley retainer for retention.

The control group also differed among the studies. In some studies, subjects presenting posterior crossbite were included in the control group, $, 8,8,16,17$ while other authors selected only patients with no posterior crossbite (normal occlusion or a different malocclusion with no transverse discrepancies) for the control group..$^{21,22}$ When these studies featured more than one control group, it was taken into account only the group of subjects with similar occlusion. ${ }^{17}$

Four studies, ${ }^{4,16,17}$ where the control group comprised subjects with posterior crossbite were approved by ethics committees and the authors followed their guidelines. Lagravere et $\mathrm{a}^{17}$ benefited from a treatment control group with delay of 12 months, and there were no negative consequences for the treatment of patients.
However, that may be an ethical issue, since delaying the correction of a problem, which is known to be better solved as early as possible may be considered unethical. This was the reason why Petrén et $\mathrm{al}^{21}$ did not include a control group of crossbite untreated subjects as their follow-up reached three years after treatment.

Overcorrection of the posterior crossbite is recommended by some authors ${ }^{4,19,28,29}$ due to the tooth crown buccal inclination, which is usually a consequence of tooth-supported expanders. ${ }^{21}$ The physiology of the relapse demonstrate that molars tend to return to their original buccolingual inclination after retention is discontinued, that would not allow relapse of the posterior crossbite if overexpansion was performed. ${ }^{11}$ Four of the included studies ${ }^{8,16,17,22}$ expanded the maxilla until the crossbite was overcorrected in all groups, particularly it was performed only in primary teeth for Cozzani et $\mathrm{al}^{8}$ and Mutinelli et al. ${ }^{16}$ In two articles ${ }^{4,21}$ however, no overexpansion was produced.

Petrén et $\mathrm{al}^{21}$ claims that overcorrection might be unnecessary, since their results without overexpansion were found to be stable in a long-term, the rate of relapse was 1.6\% in the intermolar cusp distance, even so to avoid buccal tipping of the molars, the appliance was adjusted for buccal root torque.

Authors that used Haas as retainers for at least 7 months ${ }^{16}$ and 8 months ${ }^{8}$ presented a relapse of $1.0 \%$ and $0.9 \%$ respectively, in the intermolar distance. These results may suggest that a longer time of retention after maxillary expansion - that is, more than 7 months would favor stability and less relapse. Moreover, the difference of the mean relapse was only $0.1 \mathrm{~mm}$, which may be clinically irrelevant.

Lagravere et $\mathrm{al}{ }^{17}$ who used Hyrax as a retainer, observed the highest relapse of measurements, $27 \%$ in the molar distance, probably related to patient age, since their sample of the treated group was 14 years. All others authors ${ }^{4,8,16,21,22}$ presented younger samples, between 5.1 a 9.7 years old, in the mixed dentition.

When removable appliances were used as retainers for 6 months, a relapse of $3.2 \%{ }^{4}$ and $1.2 \%{ }^{21}$ was found in the intermolar distance. Godoy et $\mathrm{al}^{4}$ instructed the patients to use the removable plate 24 hours a day for 3 months and just at night for 3 more months, while Petrén et $\mathrm{al}^{21}$ recommended a 24-hour/day use for 6 months. That may have influenced on the first authors' higher rates of relapse. 
The overall comparison among fixed and removable retainers when a six-month retention was used, showed a very small range of variation, between $1.2 \%{ }^{21}$ and $3.2 \%{ }^{4}$ in the intermolar distance. When comparing treatment groups which had as their expander/retainer the QDH and EP, Petrén et $\mathrm{al}^{21}$ observed similar results. According to Godoy et $\mathrm{al}^{4}{ }^{4}$ the greatest disadvantage of EP was lost appliances and subsequent laboratory costs, and QDH's frequent breakage. In spite of this, one of the most cited disadvantages of removable appliances in the literature is the need for patients' compliance. ${ }^{4,30}$

Primozic et $\mathrm{al}^{22}$ assessed skeletal measures through the palatal surface area. Considering a 30-month follow-up, there was no relapse in this skeletal measure. On the contrary, there was an increment of $6.38 \%$. They found that increase in the experimental group to be similar to or greater than the increase observed in the control group of normal occlusion. According to the authors, that indicates the reestablishment of a normal growth rate and the condition for normal occlusion and craniofacial development.

However, relapse in dental and skeletal measures does not necessarily represent a relapse in the posterior crossbite. Four authors have reported recurrence of posterior crossbite. That relapse is expressed in percentage of patients as reported by authors or calculated according to their data: $0 \%{ }^{16,21}$ (Haas group for at least 7 months; removable plate group, 6 months of retention), $5 \% 0^{21}$ (QDH group, 6 months of retention), 9.1\% $\%^{4}$ (QDH and removable plate, 6 months of retention), $26.7 \%{ }^{22}$ (acrylic cemented plate group, cemented as retention for 1 month and removable for 4 months). Relapse is not a rare event after correction of posterior crossbite..$^{21,22,30}$

Primozic et $\mathrm{a}^{22}$ showed the biggest recurrence of posterior crossbite after the treatment, amounting of 8 participants, they suggest that part of this relapse could be explained because the subjects expressed a Class III growth trend, inverse overjet and facial asymmetries.

Limitations of this review are: not enough RCTs were found that were able to answer our question; additionally, no study specifically aimed at answering this question, nor did any study assessed or compared different periods of retention in patients wearing the same kind of appliance. Our systematic review clearly shows the need for randomized controlled trials that specifically assess different periods of retention with the same appliances and the stability of correction of the posterior crossbite, so that a protocol may be created for successful treatment maintenance.

The clinical implication of this systematic review is that six months of retention of crossbite correction used 24 hours a day should be able to maintain the results obtained. However, the evidence for this conclusion is moderate.

\section{CONCLUSION}

Based on the results from this systematic review, there is moderate evidence to assert that six months of retention with either fixed or removable appliances seem to be enough to avoid relapse or to guarantee minimal changes in a short-term follow-up. 


\section{REFERENCES}

1. Keski-Nisula K, Lehto R, Lusa V, Keski-Nisula L, Varrela J. Occurrence of malocclusion and need of orthodontic treatment in early mixed dentition. Am J Orthod Dentofacial Orthop. 2003 Dec;124(6):631-8.

2. Tausche E, Luck O, Harzer W. Prevalence of malocclusions in the early mixed dentition and orthodontic treatment need. Eur J Orthod. 2004 June;26(3):237-44

3. Jonsson T, Arnlaugsson S, Karlsson KO, Ragnarsson B, Arnarson EO Magnusson TE. Orthodontic treatment experience and prevalence of malocclusion traits in an Icelandic adult population. Am J Orthod Dentofacial Orthop. 2007 Jan;131(1):8.e11-8.

4. Godoy F, Godoy-Bezerra J, Rosenblatt A. Treatment of posterior crossbite comparing 2 appliances: a community-based trial. Am J Orthod Dentofacial Orthop. 2011 Jan;139(1):e45-52

5. Egermark-Eriksson I, Carlsson GE, Magnusson T, Thilander B. A longitudinal study on malocclusion in relation to signs and symptoms of craniomandibular disorders in children and adolescents. Eur J Orthod. 1990 Nov;12(4):399-407.

6. Thilander B, Wahlund S, Lennartsson B. The effect of early interceptive treatment in children with posterior cross-bite. Eur J Orthod. 1984 Feb; 6(1):25-34

7. Petrén S, Bondemark L, Söderfeldt B. A systematic review concerning early orthodontic treatment of unilateral posterior crossbite. Angle Orthod. 2003 Oct:73(5):588-96.

8. Cozzani M, Guiducci A, Mirenghi S, Mutinelli S, Siciliani G. Arch width changes with a rapid maxillary expansion appliance anchored to the primary teeth. Angle Orthod. 2007 Mar;77(2):296-302.

9. Defraia E, Marinelli A, Baroni G, Tollaro I. Dentoalveolar effects induced by a removable expansion plate. Prog Orthod. 2007:8(2):260-7.

10. Flores-Mir C. Grinding is effective in early orthodontic treatment of unilateral posterior crossbite. Evid Based Dent. 2005;6(1):24.

11. Handelman CS, Wang L, BeGole EA, Haas AJ. Nonsurgical rapid maxillary expansion in adults: report on 47 cases using the Haas expander. Angle Orthod. 2000 Apr:70(2):129-44

12. Lee KJ, Park YC, Park JY, Hwang WS. Miniscrew-assisted nonsurgical palatal expansion before orthognathic surgery for a patient with severe mandibular prognathism. Am J Orthod Dentofacial Orthop. 2010 June:137(6):830-9

13. Haas AJ. Long-term posttreatment evaluation of rapid palatal expansion Angle Orthod. 1980 July;50(3):189-217.

14. Huynh T, Kennedy DB, Joondeph DR, Bollen AM. Treatment response and stability of slow maxillary expansion using Haas, hyrax, and quad-helix appliances: a retrospective study. Am J Orthod Dentofacial Orthop. 2009 Sept;136(3):331-9.

15. Wong CA, Sinclair PM, Keim RG, Kennedy DB. Arch dimension changes from successful slow maxillary expansion of unilateral posterior crossbite. Angle Orthod. 2011 July:81(4):616-23
16. Mutinelli S, Cozzani M. Rapid maxillary expansion in early-mixed dentition effectiveness of increasing arch dimension with anchorage on deciduous teeth. Eur J Paediatr Dent. 2015 June;16(2):115-22

17. Lagravère MO, Carey J, Heo G, Toogood RW, Major PW. Transverse, vertical, and anteroposterior changes from bone-anchored maxillary expansion vs traditional rapid maxillary expansion: a randomized clinical trial. Am J Orthod Dentofacial Orthop. 2010 Mar;137(3):304.e1-12; discussion 304-5.

18. Wangsrimongkol T, Manosudprasit M, Pisek P, Leelasinjaroen P. Correction of complete maxillary crossbite with severe crowding using Hyrax expansion and fixed appliance. J Med Assoc Thai. 2013 Sept;96 Suppl 4:S149-56.

19. Bell RA, Le Compte EJ. The effects of maxillary expansion using a quad-helix appliance during the deciduous and mixed dentitions. Am J Orthod. 1981 Feb;79(2):152-61.

20. Bjerklin K. Follow-up control of patients with unilateral posterior cross-bite treated with expansion plates or the quad-helix appliance. J Orofac Orthop. 2000;61(2):112-24.

21. Petrén S, Bjerklin K, Bondemark L. Stability of unilateral posterior crossbite correction in the mixed dentition: a randomized clinical trial with a 3-year follow-up. Am J Orthod Dentofacial Orthop. 2011 Jan;139(1):e73-81.

22. Primožič J, Richmond S, Kau CH, Zhurov A, Ovsenik M. Three-dimensional evaluation of early crossbite correction: a longitudinal study. Eur J Orthod. 2013 Feb; 35(1):7-13

23. Gurel HG, Memili B, Erkan M, Sukurica Y. Long-term effects of rapid maxillary expansion followed by fixed appliances. Angle Orthod. 2010 Jan;80(1):5-9.

24. Kau CH, Zhurov A, Scheer R, Bouwman S, Richmond S. The feasibility of measuring three-dimensional facial morphology in children. Orthod Craniofac Res. 2004 Nov;7(4):198-204

25. McNamara JA Jr, Lione R, Franchi L, Angelieri F, Cevidanes LH, Darendeliler MA, et al. The role of rapid maxillary expansion in the promotion of oral and general health. Prog Orthod. 2015:16:33.

26. Higgins JPT, Green S, editors. Cochrane handbook for systematic reviews of interventions. 2009. version 5.1.0, updated March 2011

27. Downs SH, Black N. The feasibility of creating a checklist for the assessment of the methodological quality both of randomised and non-randomised studies of health care interventions. J Epidemiol Community Health. 1998 June:52(6):377-84.

28. Mew J. Relapse following maxillary expansion. A study of twenty-five consecutive cases. Am J Orthod. 1983 Jan;83(1):56-61.

29. Sandikçioğlu M, Hazar S. Skeletal and dental changes after maxillary expansion in the mixed dentition. Am J Orthod Dentofacial Orthop. 1997 Mar;111(3):321-7.

30. Agostino P, Ugolini A, Signori A, Silvestrini-Biavati A, Harrison JE, Riley P. Orthodontic treatment for posterior crossbites. Cochrane Database Syst Rev. 2014 Aug 8; (8):CD000979. 